\title{
Determination of HPV DNA viral load by hybrid capture assay and its association with cytological findings
}

\section{Determinação da carga viral de DNA de HPV pelo ensaio de captura hibrida e sua associação com achados citológicos}

Inês Aparecida Tozetti'; Ilzia Doraci Lins Scapulatempo ${ }^{2}$; José Eduardo Levi³; Antonio Walter Ferreira ${ }^{4}$

key words Human papillomavirus

Viral load

Cytology

\section{abstract}

Objective: To compare the relation between HPV viral load by hybrid capture II test $(\mathrm{HCII})$ and cytological findings. Methods: Three hundred sixty-two reagent samples to HPV DNA by HCIl had their viral loads classified in four categories and correlated to cytological results. Results: Twenty-two samples (6.1\%) were reagent only to low-risk oncogenic types (group A) and 340 (93.9\%) were reagent to high-risk oncogenic types (group B). The correlation between viral load for the reagent samples to group A and cytological results showed low-grade squamous intraepithelial lesion (LSIL) predominance (50\%). Most of this group samples had viral load between 1 to <10RLU/PCA. Of the patients that were reagent to group B $52.1 \%$ had LSIL cytology and $38.2 \%$ were negative to intraepithelial lesion and malignancy (NILM) cytology. The patients with LSIL had viral load well distributed with a slight predominance of 100 to $<1,000$ RLU/PCB category. The samples had viral load between 1 to $<10$ RLU/PCB showed NILM cytology predominance (48.1\%). High-grade squamous intraepithelial lesions (3.4\%) were present on the samples with viral load between 100 to $<1,000 \mathrm{RLU} / \mathrm{PCB}(p=0.023)$. There was a correlation between the median for group $B$ viral load and LSIL/HSIL results. Conclusions: The quantification of viral load, mainly of high-risk HPV types, may be a useful tool for dealing with patients who have suspicious lesions.

Objetivo: Comparar a relação entre a carga viral do HPV por captura híbrida II (HCII) e os achados citológicos. Metodos: Trezentas e sessenta e duas amostras reagentes para DNA de HPV por HCII tiveram suas cargas virais classificadas em quatro categorias e correlacionadas aos resultados citológicos. Resultados: Vinte e duas amostras (6,1\%) foram reagentes somente para os tipos de baixo risco oncogênico (grupo A) e 340 (93,9\%) foram reagentes para os tipos de alto risco oncogênico (grupo B). A correlação entre carga viral das amostras reagentes para o grupo A e resultados citológicos mostrou predominância (50\%) de lesão escamosa intraepitelial de baixo grau (LSIL). A maioria das amostras desse grupo teve carga viral entre 1 e < 10RLU/PCA. Nos pacientes reagentes para o grupo B observamos que 52,1\% tiveram citologia LSIL e 38,2\% tiveram citologia negativa para lesão intraepitelial e malignidade (NILM). Os pacientes com LSIL tiveram a carga viral bem distribuída, com ligeira predominância da categoria de $100 a<1.000 R L U / P C B$. As amostras com carga viral entre 1 e $<10 R L U / P C B$ mostraram predominância de citologia NILM (48.1\%). Lesões escamosas de alto grau $(3,4 \%)$ foram presentes nas amostras com carga viral entre $100 e<1.000 R L U / P C B(p=0,023)$. Houve correlação entre a mediana da carga viral para o grupo B e os resultados LSIL/HSIL. Conclusões: A quantificação da carga viral, principalmente para os tipos de HPV de alto risco oncogênico, pode ser uma ferramenta útil para o acompanhamento de pacientes com lesões suspeitas.

1. Professora-adjunta do Departamento de Patologia da Universidade Federal de Mato Grosso do Sul (UFMS).

2. Professora-adjunta do Departamento de Patologia da UFMS; médica patologista do Centro de Prevenção ao Câncer, Campo Grande-MS

3. Pesquisador-doutor do Laboratório de Virologia do Instituto de Medicina Tropical de São Paulo.

4. Diretor do Instituto de Medicina Tropical de São Paulo; professor-doutor do Laboratório de Sorologia do Instituto de Medicina Tropical de São Paulo. 


\section{Introduction}

Cervical cancer is the second most common cancer among women worldwide and the human papillomavirus (HPV) is its main cause. HPV infections are associated with benign and malignant cutaneous and mucosal epithelial lesions ${ }^{(9)}$. Genital HPV types are subdivided into low-risk oncogenic types, frequently found in genital warts (types $6,11,26,42,44,54,70$ and 73), and high-risk oncogenic types, associated with squamous intraepithelial lesions and invasive cancer (types 16, 18, 31, 35, 45, 51, 52, 58 and 59)(1). However, most HPV infections are transient, without clinical lesions or atypical cytological findings.

For some authors the screening of high-risk HPV types should be done to identify lesions with potential for progression to invasive cancer ${ }^{(12)}$. There is a direct correlation between the number of copies of an oncogenic HPV type and the risk of developing HPV-related diseases ${ }^{(6)}$.

The hybrid capture II test ( $\mathrm{HCII})$ is widely used in routine analysis of cervical scrapes for HPV detection. This test uses probe cocktails that hybridize with specific HPV deoxyribonucleic acid (DNA) permitting the detection of 18 HPV types separated into two groups: low oncogenic risk (group A) and high oncogenic risk (group B). The viral load measure is obtained by comparing the relative light units of the samples to positive controls (RLU/PC).

In the present study, we compared the relation between HPV viral loads and cytological findings.

\section{Materials and methods}

There are 362 samples that were reagent to HPV DNA, analyzed by $\mathrm{HCll}$ (Digene Corporation Gaithersburg, Maryland, USA) and included in this study. After the ethics committee approval, these samples were collected from women assisted at Centro de Prevenção ao Câncer, in Campo Grande, Mato Grosso do Sul, Brazil, from 2001 to 2004. The patients came from public health services or medical clinics with clinical suspicion of HPV-associated disease, for control of infection or other cervical disease. Cervical specimens were collected with a cervical brush, put in a tube with specimen transport medium (Digene Brasil, São Paulo, Brazil) and stored at $2^{\circ} \mathrm{C}$ to $8^{\circ} \mathrm{C}$ until processing.

\section{Cytological findings}

Cytological diagnoses were reported using the 2001 Bethesda System ${ }^{(14)}$.

\section{Hybrid capture II}

The protocol was performed according to the manufacturer instructions. After subjected to low and high-risk HPV probes, samples were considered positive when the RLU/PC was $\geq 1$. According to viral load, they were classified into four groups: 1 to $<10 ; 10$ to $<100$; 100 to $<1,000$ and $\geq 1,000 \mathrm{RLU} / \mathrm{PC}^{(7)}$ and then correlated to cytological results.

\section{Statistical analyses}

Statistical analyses were performed using the Epi Info software, version 3.2, 2004 (CDC, Atlanta, Georgia). The frequency tables were analyzed using $\chi^{2}$ test, with $95 \%$ confidence limits. The correlation between results was calculated by Kruskal Wallis test for two groups.

\section{Results}

Patients were 16-64 years old (30.77 mean age). The relation between cytological findings and $\mathrm{HCll}$ results is presented on Table $1\left(\chi^{2}=0.96\right)$. Twenty-two samples (6.1\%) were reagent to low-risk oncogenic types (group A) and 340 (93.9\%) were reagent to high-risk oncogenic types (reagent to group B or groups A and B). The cytological findings were: atypical squamous cells of undetermined significance (ASCUS) in $9.1 \%$ of the smears; high-grade squamous intraepithelial lesion (HSIL) in $0.8 \%$; low-grade squamous intraepithelial lesion (LSIL) in $51.9 \%$ and negative to intraepithelial lesion and malignancy (NILM) in $38.1 \%$. $\mathrm{HSIL}$ was presented only on the samples that were reagent to group $B$ and groups $A$ and $B$.

For the reagent samples only to group A, Table $\mathbf{2}$ shows that the correlation between cytological results and viral load was not significant $(p=0.35)$. These patients had LSIL cytology predominating (50\%) and most of these samples had viral load between 1 to $<$ 10RLU/PCA.

Table 3 shows the correlation of cytological findings and viral load of the reagent samples to group $B$ or groups $A$ and $B$ $(p=0.023)$. It was observed that $52.1 \%$ of these samples had LSIL and $38.2 \%$ had NILM. Patients with LSIL had the viral load well distributed, with a slight predominance of 100 to $<1,000 R L U / P C B$ category. Samples with viral load between 1 to $<10 \mathrm{RLU} / \mathrm{PCB}$ showed predominance of NILM cytology $(\mathrm{n}=52 ; 48.1 \%)$. HSIL (3.4\%) was present only in samples which had viral load between 100 to $<1,000$ RLU/PCB.

On Table 4 mean, median and standard deviation (SD) were observed of the viral load to samples reagent 


\section{Samples reagent by HCII to high (group B) and/or low (group A) oncogenic risk HPV types in}

Table 1 relation to cytological findings

Cytology

HCII

Total

\begin{tabular}{lcccc} 
& Group A & Group A and B & Group B & \\
ASCUS & $3(9.1 \%)$ & $23(69.7 \%)$ & $7(21.2 \%)$ & $33(9.1 \%)$ \\
HSIL & $0(0 \%)$ & $2(66.7 \%)$ & $1(33.3 \%)$ & $3(0.8 \%)$ \\
LSIL & $11(5.9 \%)$ & $122(64.9 \%)$ & $55(29.3 \%)$ & $188(51.9 \%)$ \\
NILM & $8(5.8 \%)$ & $91(65.9 \%)$ & $39(28.3 \%)$ & $138(38.1 \%)$ \\
Total & $22(6.1 \%)$ & $238(65.7 \%)$ & $102(28.2 \%)$ & $362(100 \%)$ \\
\hline
\end{tabular}

ASCUS: atypical squamous cells of undetermined significance; HSIL: high-grade squamous intraepithelial lesion; LSIL: low-grade squamous intraepithelial lesion; NILM: negative to intraepithelial lesion and malignancy.

\section{Table 2 Viral load of the samples reagent only to group A in relation to cytological findings}

\begin{tabular}{lccccc}
\hline Cytology & \multicolumn{5}{c}{ Viral load (group A) } \\
& 1 to $<10$ RLU/PCA & 10 to $<100$ RLU/PCA & 100 to $<1,000$ RLU/PCA & $\geq 1,000$ RLU/PCA \\
ASCUS & $1(33.3 \%)$ & $1(33.3 \%)$ & $1(33.3 \%)$ & $0(0 \%)$ & $3(13.6 \%)$ \\
LSIL & $5(45.5 \%)$ & $3(27.3 \%)$ & $1(9.1 \%)$ & $2(18.2 \%)$ & $11(50 \%)$ \\
NILM & $6(75 \%)$ & $1(12.5 \%)$ & $1(12.5 \%)$ & $0(0 \%)$ & $8(36.4 \%)$ \\
Total & $12(54.5 \%)$ & $5(22.7 \%)$ & $3(13.6 \%)$ & $2(9.1 \%)$ & $22(100 \%)$ \\
\hline
\end{tabular}

ASCUS: atypical squamous cells of undetermined significance; LSIL: low-grade squamous intraepithelial lesion; NILM: negative to intraepithelial lesion and malignancy.

\section{Table 3 cytological findings}

\section{Viral load of the samples reagent to group B, independent of group A result, in relation to}

\begin{tabular}{lccccc}
\hline Cytology & \multicolumn{5}{c}{ Viral load (group B) } \\
& 1 to $<10$ RLU/PCB & 10 to $<100$ RLU/PCB & 100 to $<1,000$ RLU/PCB & $\geq 1,000$ RLU/PCB \\
ASCUS & $10(33.3 \%)$ & $7(23.3 \%)$ & $9(30 \%)$ & $4(13.3 \%)$ & $30(8.8 \%)$ \\
HSIL & $0(0 \%)$ & $0(0 \%)$ & $3(100 \%)$ & $0(0 \%)$ & $3(0.9 \%)$ \\
LSIL & $46(26 \%)$ & $35(19.8 \%)$ & $49(27.7 \%)$ & $47(26.6 \%)$ & $177(52.1 \%)$ \\
NILM & $52(40 \%)$ & $28(21.5 \%)$ & $26(20 \%)$ & $24(18.5 \%)$ & $130(38.2 \%)$ \\
Total & $108(31.8 \%)$ & $70(20.6 \%)$ & $87(25.6 \%)$ & $75(22.1 \%)$ & $340(100 \%)$ \\
\hline
\end{tabular}

ASCUS: atypical squamous cells of undetermined significance; HSIL: high-grade squamous intraepithelial lesion; LSIL: low-grade squamous intraepithelial lesion; NILM: negative to intraepithelial lesion and malignancy.

Table 4

Cytology

Mean, median and standard deviation (SD) of the viral load to samples reagent to group A or $B$ and cytological findings

\begin{tabular}{lcccccc} 
& Mean & Median & SD & Mean & Median & SD \\
LSIL & 265.9 & 3.15 & 723.52 & $8,895.58$ & 127.41 & $58,295.37$ \\
HSIL & 3.27 & 2.53 & 3.22 & 375.2 & 478.74 & 182.25 \\
ASCUS & 156.7 & 3.48 & 355.5 & 396.58 & 24.86 & 851.18 \\
NILM & 134.81 & 3.15 & 382.51 & $2,059.54$ & 21.49 & $16,548.62$ \\
\hline
\end{tabular}

ASCUS: atypical squamous cells of undetermined significance; HSIL: high-grade squamous intraepithelial lesion; LSIL: low-grade squamous intraepithelial lesion; NILM: negative to intraepithelial lesion and malignancy. 
to group A or B in correlation to cytological findings. A positive correlation was found between median of group $B$ viral load and LSIL/HSIL cytology.

\section{Discussion}

Although new alternatives have been proposed, there is a consensus on the $\mathrm{HC}$ indication for cases diagnosed as $\operatorname{ASCUS}^{(15,16)}$. The use of the diagnostic tests for HPV DNA in combination with cytology has been recommended by some authors because it enhances the performance of both tests ${ }^{(6,7)}$. HPV DNA detection was considered relevant in screening patients with normal and ASCUS cytology because, if high-risk HPV is found, they may represent people who have high probability of showing abnormal cytology and cervical disease in the future ${ }^{(4,8)}$. The results showed that $9.1 \%$ of the reagent patients to HPV DNA had cytological diagnosis of ASCUS and $38.1 \%$ had NILM (Table 1). In other reports the rate referred to HPV DNA by HCIl was $16 \%$ in women with ASCUS cytology and $29.6 \%$ in women with normal smears ${ }^{(2,11)}$.

In this work $51.9 \%$ of the reagent patients to HPV DNA, mainly to high-risk types, were found to have LSIL. It is in accordance with other reports that confirm the association of HPV and intraepithelial lesions ${ }^{(2,11)}$. Some authors showed that the amount of HPV DNA is related to the grade of intraepithelial lesions and patients with high viral load, of group B HPV types, have greater risk of intraepithelial lesions or cervical cancer ${ }^{(4,8)}$. The results are in agreement with other reports, which noted HSIL presence only in samples reagent to high-risk HPV and with high viral load $(2,5,11,13$, 17). A positive correlation was observed between group $B$ viral load median and LSIL/HSIL, values above 25RLU/PCB could be of clinical significance. For group $A$, median values were basically the same to all four cytological classifications.
Hernández-Hernández et al. showed that the low viral load of group B HPV was present in patients with negative cytology, and the high viral load, in patients with NIC II/III. They suggested a strong relation between grade of lesion and viral load ${ }^{(5)}$.

Federschneider et al. pointed out that in samples with results of 1 to $3 \mathrm{RLU} / \mathrm{PCB}$ the agreement between polymerase chain reaction (PCR) and $\mathrm{HCll}$ is poor and these results had low reproducibility and predictive value ${ }^{(3)}$. Santos et al. observed that 10RLU/PCB as cutoff point in $\mathrm{HC} 2$ represented the best balance between sensitivity and specificity. They proposed that viral load index values (RLU) should be categorized to estimate the disease progression ${ }^{(11)}$. The viral load from 1 to 10RLU is one of low specificity and in these levels may represent false-positive results or HPV with no further clinical implication. These findings are supported by other authors that used PCR to confirm them ${ }^{(10)}$.

Some studies confirmed that the high viral load of group B HPV could be used as a marker of progression to precancerous lesions, although lower viral load does not exclude progressive disease ${ }^{(10,11)}$. The quantification of viral load, mainly of high-risk HPV types, may be a useful tool for dealing with patients who bear suspicious lesions and in these cases values $>25 R L U / P C B$ should be considered a key point. Finally, a guideline to the applicability of viral load values for patient management is certainly necessary, but still a not available tool. This study presents a suggestion of clinical cut-off of 25RLU for the high-risk probe, similar to other published data ${ }^{(13,17)}$. However, due to the large standard deviations found for both probes and cytological classifications, these guidelines shall be used with caution and in the context of general clinical presentation to guide the attendance of patients with negative cytology or ASCUS and prevent the progression of HPV infection.

\section{References}

I. BOSCH, F. X. et al. Papillomavirus research update: highlights of the Barcelona international papillomavirus conference. / Clin Pathol, v. 54, p. I63-75, 2001.

2. CARVALHO, M. O. O. et al. Detection of human papillomavirus DNA by the hybrid capture assay. Braz J Infec Dis, v. 7, p. I $21-5,2003$

3. FEDERSCHNEIDER, J. M. et al.The borderline or weakly positive hybrid capture II HPV test: a statistical and comparative (PCR) analysis. Am J Obst and Gynecol, v. I91, p. 757-61, 2004.

4. FERRECCIO, C. et al. A comparison of single combined visual, cytologic, and virologic tests as screening strategies in region at high risk of cervical cancer. Cancer Epidemiol Biomarkers Prev, v. I2, n. 9, p. 8I5-23, 2003

5. HERNÁNDEZ-HERNÁNDEZ, D. M. et al. Association between high-risk human papillomavirus DNA load and precursor lesions of cervical cancer in Mexican women. Gynecol Oncol, v. 90, p. 310-7, 2003

6. HUBARD, R. A. Human papillomavirus testing methods. Arch Pathol Lab Med, v. 127, n. 8, p. 940-5, 2003.

7. LORINCZ, A. T. et al. Viral load of human papillomavirus and 
risk of CIN 3 or cervical cancer. Lancet, v. 360, n. 9328, p. 228-9, 2002.

8. LORINCZ, A. T.; RICHART, R. M. Human papillomavirus DNA testing as an adjunct to cytology in cervical screening programs. Arc Pathol Lab Med, v. I27, n. 8, p. 959-68, 2003.

9. MUÑOZ, N. et al. Epidemiologic classification of human papillomavirus types associated with cervical cancer. N Engl J Med, v. 348, p.5।8-27, 2003.

10. RABELO-SANTOS, S. H. et al. DNA recovery from hybrid capture II samples stored in specimen transport medium with denaturing reagent, for the detection of human papillomavirus by PCR. J Virol Methods, v. 126, p.197-201, 2005.

I I. SANTOS, A. L. F. et al. Human papillomavirus viral load in predicting high-grade CIN in women with cervical smears showing only atypical squamous cells or low-grade squamous intraepithelial lesion. São Paulo Med J, v. I21, n. 6, p. 238-43, 2003.

12. SASLOW, D. et al. American Cancer Society guideline for early detection of cervical neoplasia and cancer. CA Cancer J Clin, v. 52, p. 342-62, 2002.

13. SCHLECHT, N. F. et al.Viral load as a predictor of the risk of cervical intraepithelial neoplasia. Int J Cancer, v. 103, p. 519 24, 2003.

14. SOLOMON, D. et al.The 200 I Bethesda System: terminology for reporting results of cervical cytology.JAMA, v. 287, n. 16, p. 21 1 4-9, 2002.

15. MAKSEN, J. A. et al. Resolving ASCUS without recourse to HPV testing: manual reprocessing of residual automated liquid-based cytology (ALBC) material using manual liquid-based cytology (MBLC). Diagn Cytopathol, v. 33, n. 6, p. 434-40, 2005.

16. KULASINGAM, S. L. et al. Cost effectiveness analysis based on the atypical squamous cells of undetermined significance/lowgrade squamous intraepithelial lesion. Triage Study ALTS. J Natl Cancer Inst, v. 98, n. 2, p. 92-100, 2006.

17. SUN, C. A. et al.Viral load of high-risk human papillomavirus in cervical squamous intraepithelial lesions. Int J Gynaecol Obst, v. 76, n. I, p. 4I-7, 2002 